\title{
A TALE OF TWO KITTIWAKES
}

PETER TAYLOR, Box 597, Pinawa, MB ROE 1L0

As the month of November progresses, fall migration draws to a close and birding opportunities in southern Manitoba diminish. The last places to look for migrants are along major rivers, where a few water birds linger well into November, and even early December. The stretch of the Winnipeg River near Pine Falls, just upstream from its mouth in Lake Winnipeg, has proven rewarding at this season in recent years. Therefore, I set out for Pine Falls with high hopes on 16 November 1996. A major blizzard in the forecast hinted that this might be the last day of fall, as birders know it.

There was entertainment along the way. I was amused by the antics of a Common Raven, which tweaked the wings and tail of an immature Bald Eagle that was feeding on a fox carcass near the highway. A Northern Hawk Owl gave a hint of the exceptional winter influx to come. When I finally reached the hydroelectric dam at Powerview, near Pine Falls, the river downstream was thronged with gulls. I estimated about 800 Herring Gulls in a restless flock that repeatedly took off from the river, climbed and headed south for a kilometre or so, then thought better and circled back and landed. It looked as though they would have to stay and weather the approaching storm. Careful scanning of the gull flock rewarded me with sightings of four Glaucous Gulls, one Thayer's Gull, and one Iceland (Kumlien's) Gull. Normally, any one of these would be a major highlight on a late fall day; to find such numbers was unprecedented.
I drove from place to place, trying different vantage points to check for other interesting birds, and managed to find straggling individuals of several grebe and duck species, including three Oldsquaws. All this was excitement enough, but I was hardly prepared for what lay ahead, literally, as I drove across the dam for about the fifth time. On the road in front of me was a smaller gull, evidently just struck by a vehicle. I quickly pulled over, ran back to check the casualty, and was amazed to find it was a firstwinter Black-legged Kittiwake. Still warm and limp, it had been dead no more than a minute or two. Talk about mixed feelings, the excitement of discovery was mixed with sadness at this rare stray's freakish demise (not to mention the fact that it was not "countable" by the American Birding Association's rules!).

The specimen was in good condition, so I took it home and arranged to forward it to Dr. Spencer Sealy, who accepted it for the bird collection at the Zoology Department of the University of Manitoba in Winnipeg. A photograph of the kittiwake accompanies this article.

This bird was only the second Black-legged Kittiwake to be recorded in southern Manitoba. The first, also in first-winter plumage, was found on 25 November 1995 under even stranger, but happier circumstances. Joanne Manary discovered this bird resting on her vehicle in the parking lot of Stony Mountain Penitentiary, north of Winnipeg! It was easily caught, and was eventually forwarded to the animal hospital at 


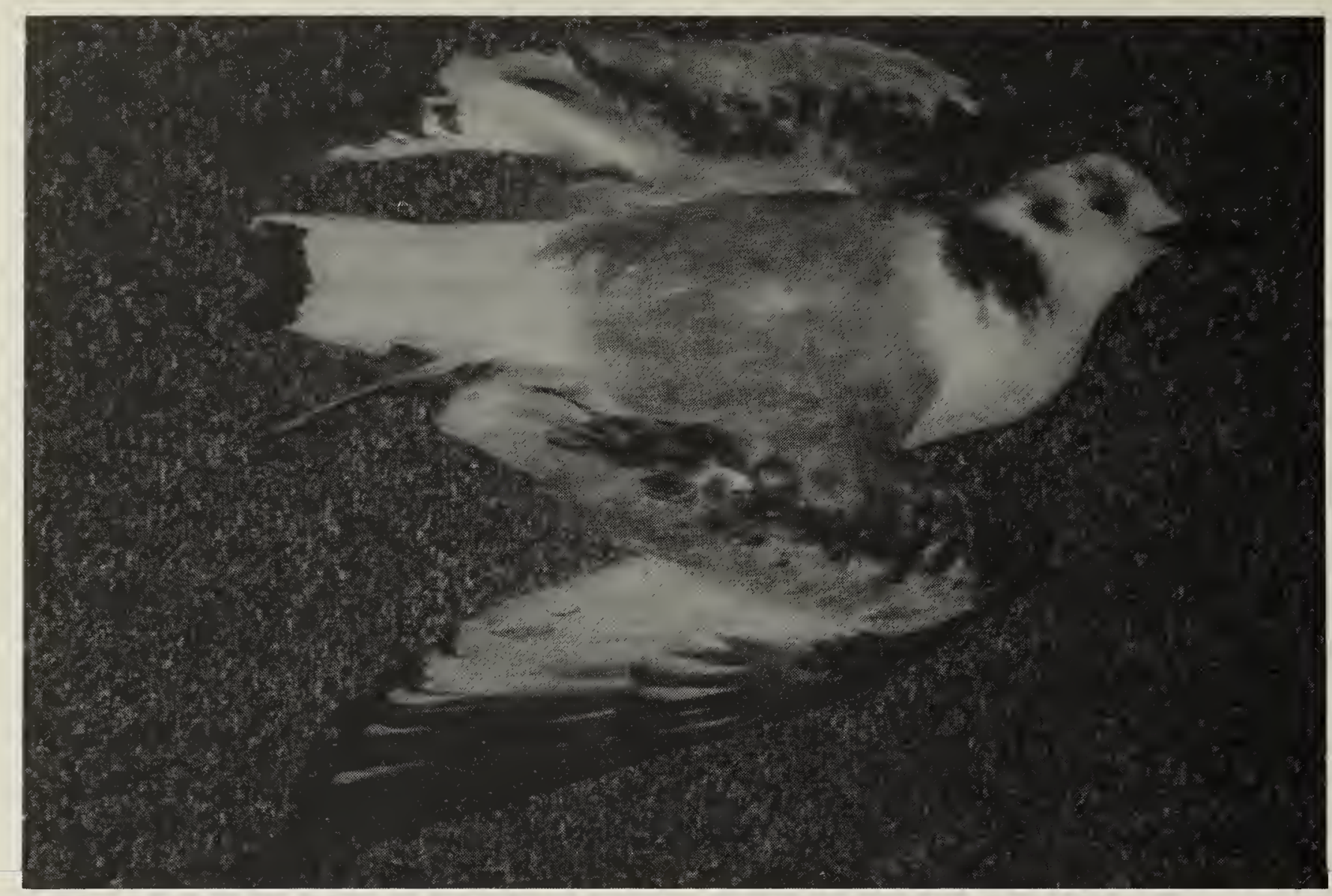

Black-legged Kittiwake found dead at Pine Falls Generating Station,

Powerview, Manitoba on 16 November 1996

Peter Taylor

Winnipeg's Assiniboine Park Zoo. While in the zoo's care, the bird's identity was confirmed by Rudolf Koes on 3 December. After fattening up on goldfish, this lucky bird was flown to Vancouver to complete its recovery for eventual release.

The Black-legged Kittiwake is a cliff-nesting, sea-going gull that nests on northerly coasts of North America and Eurasia and winters mainly at sea. Small numbers occur regularly in the lower Great Lakes region, and the species is a rare wanderer elsewhere in the North American interior. In southern Ontario, for example, it occurs mainly between late April and late May, and from mid-September to late December. ${ }^{2}$ In 1983, Smith and Kuyt compiled 15 records from the Prairie Provinces and nearby states. ${ }^{8}$ All but three of these records were in fall or winter, mainly November and December, and most were first-winter birds. Smith and Kuyt speculated that such birds were displaced eastward by low pressure systems moving eastward out of the north Pacific. ${ }^{8}$ A number of additional records, including those described here, fall into this pattern of late fall wandering by young birds. $1,3,7,8,10$

Two records in adjoining regions roughly coincide with the Pine Falls, Manitoba bird. Saskatchewan's third Black-legged Kittiwake was found near Gardiner Dam on 7 December 1996, and one was seen at Lake Winnibigoshish, Minnesota on 10 November 1996; both were first-winter birds. ${ }^{6,9}$ The latter, however, may have been a rediscovery of a bird seen in September. Exceptions to the late-fall pattern of occurrence include the four or five birds seen at Churchill, Manitoba, most or all of them adults, in June or July. ${ }^{4,5}$ These were most likely members of the Arctic breeding population that strayed into Hudson Bay. Alberta also boasts June and July sightings of this species. ${ }^{1}$ The occurrence of several spring records in South Dakota and Minnesota indicates that the 
occasional Black-legged Kittiwake may also turn up in the Prairie Provinces in spring. ${ }^{3,10}$

1. Chytyk, P. 1990. Saskatchewan's first Black-legged Kittiwake. Blue Jay 48: 112-114.

2. James, R.D. 1991. Annotated checklist of the birds of Ontario. Second, revised edition. Royal Ontario Museum, Toronto, $128 \mathrm{pp}$.

3. Janssen, R.B. 1988. Birds in Minnesota. University of Minnesota Press, Minneapolis, 352 pp.; also, several more recent reports published in The Loon.

4. Koes, R.F. 1991. Additions to the Manitoba bird list (1985-1990). Blue Jay 49:202-207.

5. Koes, R.F. and P. Taylor. 1995. Prairie
Provinces Region. National Audubon Society Field Notes 49:941-943.

6. Kreba, R. and B. Luterbach (compilers). 1997. Cross Canada round-up: Saskatchewan. Birders Journal 6:6-7.

7. Smith, A.R. 1996. Atlas of Saskatchewan birds. Special Publication No. 22, Saskatchewan Natural History Society, Regina. 456 pp.

8. Smith, A.R. and E. Kuyt. 1983. Occurrences of the Black-legged Kittiwake, Rissa tridactyla, in the Prairie Provinces and north-central United States. Can. Field-Nat. 97:111-113.

9. Svingen, P. 1997. Another sighting of a Black-legged Kittiwake on Lake Winnibigoshish. The Loon 68:247.

10. The South Dakota Ornithologists' Union. 1991. The birds of South Dakota. Second Edition. 411 pp.

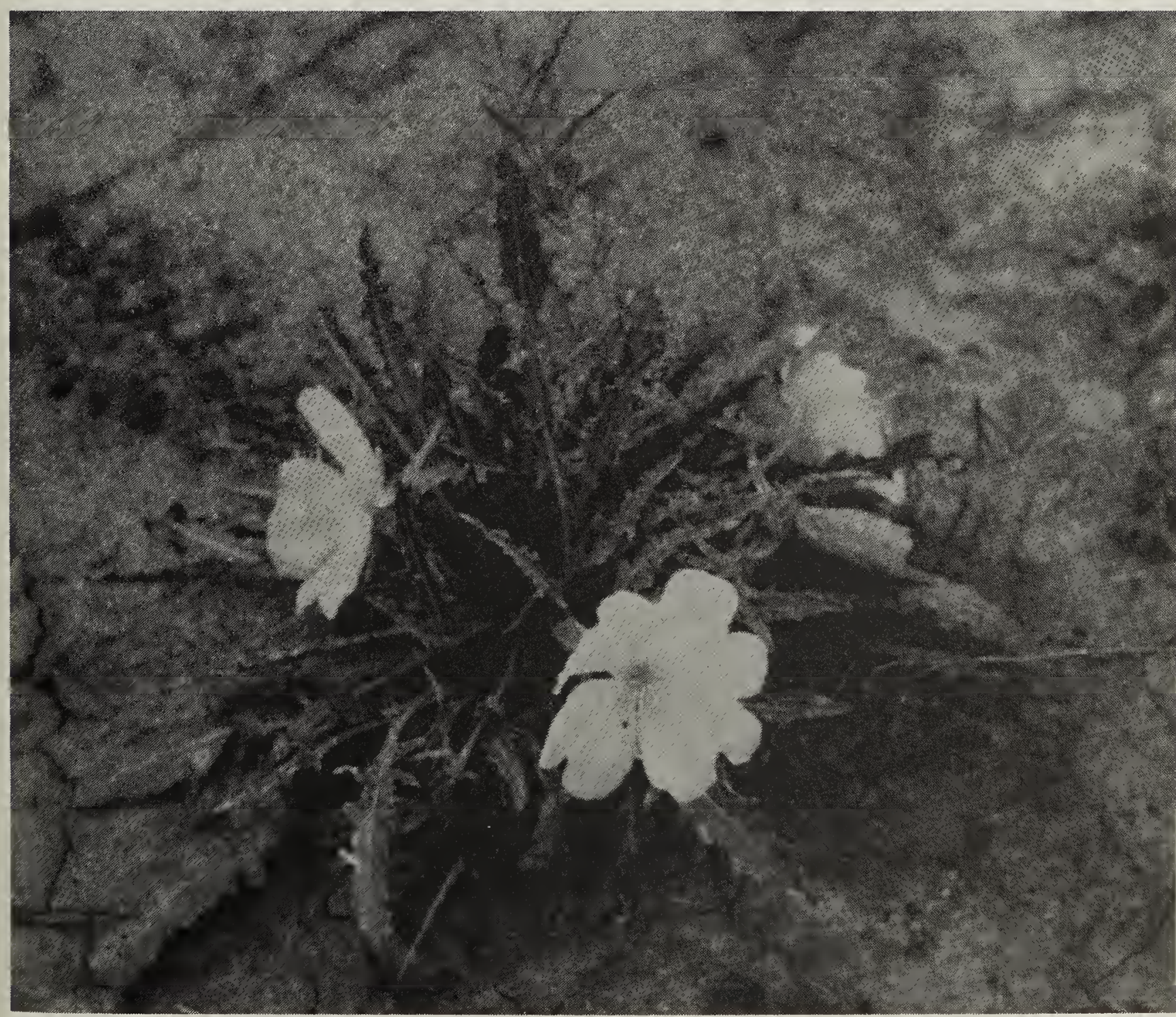

